$B J M G 11 / 2(2008) 65-68$

$10.2478 / \mathrm{v} 10034-008-0023-\mathrm{z}$

SHORT COMMUNICATION

\title{
PALLISTER-KILLIAN SYNDROME: RARE PHENOTYPIC FEATURES AND VARIABLE KARYOTYPES
}

\author{
Liehr $\mathrm{T}^{1, *}$, Wegner R-D ${ }^{2}$, Stumm $\mathrm{M}^{2}$, Joksić $\mathrm{G}^{3}$, Polityko $\mathrm{A}^{4}$, \\ Kosyakova $N^{1}$, Ewers $E^{1}$, Reich $D^{1}$, Wagner $\mathrm{R}^{1}$, Weise $\mathrm{A}^{1}$
}

\begin{abstract}
*Corresponding Author: Dr. Thomas Liehr, Institut für Humangenetik, Postfach D-07740 Jena, Germany; Tel: +49-3641-935533; Fax.++49-3641-935582; e-mail: i8lith@mti.uni-jena.de
\end{abstract}

The Pallister-Killian Syndrome (PKS; OMIM \#601803), also known as Tetrasomy 12p or Mosaic Isochromosome $12 \mathrm{p}$ syndrome, is a rare genetic disorder in humans. Its exact incidence is not known. The PKS is due to a partial tetrasomy of the whole, or parts of, the short arm of chromosome 12. It was first described by Philip Pallister in 1977 and further studied by Maria Teschler-Nicola and W. Killian in 1981. Prenatally, PKS can be suggested due to relatively unspecific abnormal sonographic findings such as enhanced nuchal transluciency or abnormal hands or feet, as well as omphalocele. In a newborn or small child, PKS can be diagnosed with facial anomalies, streaks of hypo- or hyper-pigmentation, seizures and profound mental retardation. Characteristic for PKS is a tissue-limited mosaicism; i.e., most fibroblasts have 47 chromosomes with an extra small metacentric iso-chromosome i(12)(p10), whereas the karyotype in the majority of the lymphocytes is normal (see OMIM \#601803).

1 Institut für Humangenetik und Anthropologie, Kollegiengasse 10, D-07743 Jena, Germany

2 Zentrum für Pränataldiagnostik, Kurfürstendamm 199, D-10719 Berlin, Germany

3 Vinca Institute of Nuclear Sciences, POB 522, in cooperation with Institute of Laboratory Medicine Aqualab, 11.000 Belgrade, Serbia

4 Republican Medical Center "Mother and child", Scientific department, Orlovskaya str, 66, bl.8, Minsk 220053, Republic of Belarus
Even though PKS is a well-known syndrome in most recent reports [1-4], the authors are not aware of the number of previously published cases. As reviewed on the regularly updated homepage on small supernumerary marker chromosomes (sSMC) [5] on the sub-page for PKS [6], there were, up to November 2008, 103 prenatal and 129 postnatal PKS reported in the literature, including the five new prenatal cases summarized in Table 1 .

Thus, of the four well-defined syndromes characterized by an SSMC, PKS is the second most frequently reported $(8.4 \%)$ (this frequency is deduced from the data collected in Ref. 5), after Emanuel Syndrome (OMIM \#609029) and ahead of isochromosome 18p syndrome [7] and cat eye syndrome (OMIM \#115470).

More interesting is, that a variety of karyotypes have been reported in association with PKS, besides the regular ones with $47,+\mathrm{i}(12 \mathrm{p})$ and mos $47,+\mathrm{i}(12 \mathrm{p}) / 46$. Unexpected cytogenetic results are sometimes detected even though the PKS phenotype is clear (Table 2) or there is no sSMC [8]. In PKS with sSMC, more complex mosaics have been reported as in cases A-D of Table 2, including complete trisomy 12 and hexasomy 12p. Three cases (E-G) in Table 2 with neocentric sSMC (12) suggest a possible small PKS critical region in 12pter to $12 \mathrm{p} 13$. Thus, additional case reports can be expected to further increase our clinical and cytogenetic understanding of PKS. Nonetheless, to come to an approximate assessment of the frequency of PKS in the general population, also cases with a "typical 
Table 1. Five new prenatally diagnosed PKS cases: tissue studied, karyotype and clinical details are listed.

\begin{tabular}{|l|l|l|l|}
\hline Case Number [6] & Tissue Studied & Clinical Details & Karyotype \\
\hline 12-Wpks-5 & chorion & AMA; AS; hygroma colli; TOP & $47, \mathrm{XX},+\mathrm{i}(12 \mathrm{p})[50 \%]$ \\
\hline 12-Wpks-166 & amnion & AMA; AS; TOP & $47, \mathrm{XX},+\mathrm{i}(12 \mathrm{p})[100 \%]$ \\
\hline 12-Wpks-167 & amnion & AMA; AS; TOP & $47, \mathrm{XX},+\mathrm{i}(12 \mathrm{p})[100 \%]$ \\
\hline 12-Wpks-173 & amnion & AMA; TOP & $47, \mathrm{XX},+\mathrm{i}(12 \mathrm{p})[67 \%]$ \\
\hline 12-Wpks-185 & amnion & AMA; AS; TOP & $47, \mathrm{XY},+\mathrm{i}(12 \mathrm{p})[50 \%]$ \\
\hline
\end{tabular}

AMA: advanced maternal age; AS: abnormal sonography; TOP: termination of pregnancy.

Table 2. Seven reported PKS cases with unusual karyotypes.

\begin{tabular}{|c|c|c|c|}
\hline Case & Case Number [6] & $\begin{array}{l}\text { Prenatal/ } \\
\text { Postnatal }\end{array}$ & Karyotype \\
\hline A & 12-Wpks-4 & postnatal & $\begin{array}{l}\text { various mosaics of } 47, \mathrm{XX},+\mathrm{i}(12 \mathrm{p}) / 47, \mathrm{XX},+\operatorname{del}(12) \\
(\mathrm{q} 10) / 46, \mathrm{XX} \text { in different tissues }\end{array}$ \\
\hline B & 12-Wpks-47 & prenatal & $48, X X,+i(12 p),+i(12 p)[16 \%]$ \\
\hline $\mathrm{C}$ & 12-Wpks-159 & prenatal & $47, \mathrm{XX},+12[20 \%] / 47, \mathrm{XX},+\mathrm{i}(12 \mathrm{p})[80 \%]$ \\
\hline $\mathrm{D}$ & 12-Wpks-174 & postnatal & $47, \mathrm{XX},+\mathrm{i}(12 \mathrm{p})[29 \%] / 47, \mathrm{XX},+\operatorname{del}(12)(\mathrm{q} 10)[43 \%]$ \\
\hline $\mathrm{E}$ & $12-\mathrm{N}-\mathrm{pt} 13 / 1-1$ & postnatal & 47,XX,+inv dup(12)(pter?p13::p13 $\rightarrow$ pter $)[100 \%]$ \\
\hline $\mathrm{F}$ & $12-\mathrm{N}-\mathrm{pt} 12.3 / 1-1$ & postnatal & $47, X X,+\operatorname{inv} \operatorname{dup}(12)($ pter?p12.3::p12.3 $\rightarrow$ pter $)[50 \%]$ \\
\hline G & $12-\mathrm{N}-\mathrm{pt} 11.22 / 1-1$ & postnatal & $47, \mathrm{XY},+$ inv dup(12)(pter?p11.22::p11.22 $\rightarrow$ pter $)[36 \%]$ \\
\hline
\end{tabular}

Tetrasomy 12p" karyotype, should be reported, as the five of the present paper.

\section{ACKNOWLEDGMENTS}

This study was supported in part by DFG (436 RUS 17/135/03; 436 RUS 17/109/04, 436 WER 17/1/04, 436 WER 17/5/05, WE 3617/2-1) and DAAD (A0703172/ Ref.325, D07/00070) and Prochance 2008, FSU Jena.

\section{REFERENCES}

1. Liberati M, Melchiorre K, D’Emilio I, Guanciali-Franchi PE, Iezzi I, Rotmensch S, Celentano C. Fetal facial profile in Pallister-Killian syndrome. Fetal Diagn Ther 2008; 23(1): 15-17.
2. Abad DE, Gabarre JA, Izquierdo AM, López-Sánchez C, García-Martínez V, Izquierdo AG. Pallister-Killian syndrome presenting with a complex congenital heart defect and increased nuchal translucency. J Ultrasound Med 2006; 25(11): 1475-1480.

3. Langford K, Hodgson S, Seller M, Maxwell D. Pallister-Killian syndrome presenting through nuchal translucency screening for trisomy 21 . Prenat Diagn 2000; 20(8): 670-672.

4. Antonella V, Pantaleo G, Anna Irma C, Savino C, Selvaggi L. Pallister-Killian syndrome presenting through nuchal oedema: cytogenetic investigation and parental origin by molecular analysis in a new case. Prenat Diagn 2004; 24(3): 229-230.

5. Liehr T. Homepage on small supernumerary 
marker chromosomes (sSMC). http://www.med. uni-jena.de/fish/sSMC/ 00START.htm.

6. Liehr T. Homepage on small supernumerary marker chromosomes (sSMC) sub-page for PKS. http://www.med. uni-jena.de/fish/sSMC/12. htm\#PKS.

7. Bugge M, Blennow E, Friedrich U, Petersen MB, Pedeutour F, Tsezou A, Orum A, Hermann S, Lyngbye T, Sarri C, Avramopoulos D, Kitsiou S, Lambert JC, Guzda M, Tommerup N, Brøndum-
Nielsen K. Tetrasomy $18 p$ de novo: parental origin and different mechanisms of formation. Eur $\mathrm{J}$ Hum Genet 1996; 4(3): 160-167.

8. Powis Z, Kang SH, Cooper ML, Patel A, Peiffer DA, Hawkins A, Heidenreich R, Gunderson KL, Cheung SW, Erickson RP. Mosaic tetrasomy $12 p$ with triplication of $12 p$ detected by array-based comparative genomic hybridization of peripheral blood DNA. Am J Med Genet A 2007; 143A(24): 2910-2915. 